\title{
Peran Ibu sebagai Edukator dan Konsumsi Sayur Buah pada Anak
}

\section{The Mother's Role as Educator and Fruit Vegetable Consumption in Children}

\author{
Putri Atika Afif* ${ }^{1}$, Sri Sumarmi ${ }^{2}$
}

\begin{abstract}
ABSTRAK
Latar Belakang: Konsumsi sayur dan buah pada anak usia sekolah masih tergolong rendah dan belum memenuhi anjuran WHO sebesar $400 \mathrm{gr} /$ hari. Banyak faktor yang mempengaruhi konsumsi sayur buah pada anak, terutama terkait peran ibu dan ketersediaan sayur buah di rumah.

Tujuan: Menganalisis hubungan peran ibu dan ketersediaan sayur buah di rumah dengan tingkat konsumsi sayur buah pada anak usia sekolah.

Metode: Penelitian dengan desain cross sectional dilakukan di SDN Kandang Tepus 01 dan SDN Kandang Tepus 02 Desa Senduro Kabupaten Lumajang dengan jumlah sampel 41 anak kelas 4 dan 5 beserta ibu. Variabel yang diamati dalam penelitian ini adalah peran ibu sebagai edukator dan inisiator untuk buah dan sayur, ketersediaan sayur dan buah di rumah dan konsumsi sayur dan buah pada anak. Pengumpulan data dilakukan dengan metode wawancara dengan instrumen kuesioner dan food frequency semi kuantitatif.

Hasil: Besar presentase anak yang mengonsumsi sayur buah sesuai anjuran $400 \mathrm{gr} /$ hari yaitu 17,1\% dari 41 anak. Hasil uji chi-square menunjukkan ada hubungan antara peran ibu sebagai edukator ( $p$ value $=0,014)$ dan ketersediaan sayur buah di rumah ( $p$-value $=0,003$ ) dengan konsumsi sayur buah pada anak. Ada hubungan peran ibu sebagai edukator dengan ketersediaan sayur buah di rumah ( $p$ value $=0,028$ ). Namun tidak ada hubungan antar peran ibu sebagai inisiator dengan konsumsi sayur buah pada anak.

Kesimpulan: Peran ibu sebagai edukator berhubungan dengan konsumsi sayur buah pada anak karena terkait dengan penyediaan sayur dan buah di rumah.
\end{abstract}

Kata Kunci: edukator, ketersediaan, sayur dan buah, konsumsi, anak 
Background: The consumption of vegetable and fruit among school age children is inadequate and below WHO recommendation (400gr/day). There are many important factors influence the children's consumption of vegetable and fruit such as mother's role and fruit and vegetable stock in household.

Objectives: To analyze the relationship between mother's role and fruit and vegetable stock in household with the children's consumption level of fruit and vegetable.

Methods: Research with cross sectional method was conducted in SDN Kandang Tepus 01 and SDN Kandang Tepus 02 Senduro village, Lumajang regency with sample 41 children grade 4 and 5 with their mother. Variable that observed in this research are mother's role as educator and inisiator of vegetable and fruit stock in home and the children consumption of vegetable and fruit. Data was collected with interview using questionnaire instrument and semi quantitative food frequency.

Results: Children who consume vegetable and fruit based on WHO recommendation $400 \mathrm{gr} /$ day was 17.1\%. Chi-square test showed that there was relathionship between mother's role as educator ( $p$ value $=0.014$ ) and stock of vegetable and fruit in household ( $p$-value $=0.003$ ) with the children's consumption of vegetable and fruit ( $p$-value $=0.028$ ). But there was no relationship between mother's role as initiator with children's consumption of vegetable and fruit.

Conclusion: Mother's role as educator related to children's consumption of vegetable and fruit because its depend on stock of fruit and vegetable in household.

Keywords: educator, availability, vegetable and fruit, children, consumption

\footnotetext{
*Koresponden: putriatika08@yahoo.com

${ }^{1}$ Departemen Gizi Kesehatan, Fakultas Kesehatan Masyarakat-Universitas Airlangga
}

\section{PENDAHULUAN}

Konsumsi sayur dan buah pada anak usia sekolah di Indonesia masih tergolonng rendah. Data Riskesdas ${ }^{1}$ menunjukkan bahwa hanya $18,2 \%$ anak usia sekolah (10-14 tahun) yag mengkonsumsi sayur dan buah sesuai anjuran 3-4 porsi/hari. Presentase tersebut merupakan presentase terendah jika dibandingkan dengan kelompok usia remaja, dewasa dan lansia. Beberapa penelitian di berbagai negara menunjukkan konsumsi sayur buah pada anak masih rendah. Penelitian di 39 Negara di Eropa, Amerika dan Canada membuktikan sebanyak $33,1 \%$ anak mengonsumsi sayur dan $36,6 \%$ anak yang mengonsumsi buah sesuai anjuran, sedangkan penelitian di Netherland menunjukkan hanya $28,6 \%$ anak yang mengonsumsi sayur buah sesuai anjuran WHO. ${ }^{2,3}$ Anak - anak di Amerika Serikat dan Eropa cenderung lebih menyukai konsumsi makanan tinggi kalori dibandingkan konsumsi sayur dan buah. ${ }^{4}$

$\mathrm{Di}$ Indonesia, anjuran untuk mengonsumsi sayur dan buah diatur dalam Permenkes Nomor 41 Tahun 2014 tentang
Pedoman Gizi Seimbang yaitu 300-400 gr/hari bagi anak usia sekolah. Anjuran konsumsi sayur dan buah menurut WHO $(2003)^{5}$ sebesar $400 \mathrm{gr} /$ hari yang terdiri dari $250 \mathrm{gr}$ sayuran dan $150 \mathrm{gr}$ buah. Kandungan vitamin, mineral, serat dan zat fitokimia dalam buah dan sayur penting bagi tumbuh kembang anak-anak. Pada masa tumbuh kembang, zat mikronutrien dibutuhkan dalam perkembangan fisik, pematangan intelektual dan sosial, sistem imun dan sistem hormon serta merupakan salah satu tindakan preventif dalam mencegah penyakit degeneratif di usia dewasa atau lanjut usia., ${ }^{6,5}$ Beberapa faktor dapat mempengaruhi konsumsi sayur dan buah pada anak antara lain pola konsumsi orang tua dan ketersediaan sayur dan buah di rumah. ${ }^{7}$ Beberapa penelitian menunjukkan bahwa ada hubungan yang positif antara pola konsumsi anak dan orang tua serta peran orang tua sehari hari juga dapat mempengaruhi pola konsumsi anak. ${ }^{8,9}$ Menurut McGuigan $(2012)^{10}$, ibu berperan penting dalam semua aspek yang berkaitan dengan kesehatan keluarga termasuk dalam pengaturan makan keluarga. Ibu juga 
bertindak sebagai edukator, fasilitator dan motivator dalam mencegah dan menangani berbagai masalah kesehatan keluarga. Penelitian ini bertujuan untuk menganalisis hubungan peran ibu dan ketersediaan sayur buah di rumah dengan konsumsi sayur buah pada anak usia sekolah di Desa Senduro Kabupaten Lumajang.

\section{METODE}

Penelitian dengan desain cross sectional telah dilakukan pada Bulan Mei hingga Juli 2017 di SDN Kandang Tepus 01 dan SDN Kandang Tepus 02 Desa Senduro Kabupaten Lumajang. Populasi penelitian adalah seluruh ibu dan siswa kelas 4 dan 5 SDN Kandang Tepus 01 dan SDN Kandang Tepus 02 tahun ajaran 2016/2017 yang sebesar 73 ibu dan anak. Perhitungan sampel menggunakan rumus proporsi binomunal, diperoleh sampel sebesar 41 sampel anak sekolah beserta ibu yang terpilih sebagai sampel dengan kriteria anak dan ibu tinggal serumah dan sehat.

Variabel penelitian yang diamati adalah peran ibu sebagai edukator, peran ibu sebagai inisiator, ketersediaan sayur dan buah di rumah dan konsumsi sayur dan buah pada anak. Pengambilan data peran ibu sebagai edukator, inisiator dan ketersediaan sayur dan buah di rumah dilakukan dengan metode wawancara kepada ibu menggunakan instrumen kuesioner terstruktur sedangkan data tingkat konsumsi diambil dengan metode wawancara kepada anak dengan instrumen FFQ semi kuantitatif. Analisis hubungan peran ibu dan ketersediaan sayur buah di rumah dengan konsumsi sayur dan buah pada anak diolah dengan uji chi-square.

\section{HASIL DAN PEMBAHASAN}

\section{Karakteristik Responden Ibu dan Anak}

Karakteristik responden ibu yang diamati meliputi umur, pekerjaan dan tingkat pendidikan sedangkan karakteristik yang diamati pada anak antara lain kelas dan jenis kelamin anak. Tabel 1 menunjukkan distribusi karakteristik responden ibu dan siswa-siswi di SDN Kandang Tepus 01 dan SDN Kandang Tepus 02 Desa Senduro Kabupaten Lumajang.
Distribusi karakteristik berdasarkan usia ibu menunjukkan bahwa sebesar $41,5 \%$ ibu termasuk dalam kelompok usia dewasa awal, $41,5 \%$ ibu termasuk dalam kelompok usia dewasa akhir dan 17,1\% ibu termasuk dalam kelompok lansia awal.

Distribusi karakteristik pekerjaan ibu menunjukkan bahwa sebagian besar ibu bekerja sebagai petani/peternak $(48,8 \%)$, bekerja sebagai ibu rumah tangga $(43,9 \%)$ dan bekerja sebagai wiraswasta $(7,3 \%)$. Terdapat perbedaan pola asuh antara ibu bekerja dengan ibu rumah tangga terkait dengan pola pemberian makan. ${ }^{11}$ Tingkat pendidikan orang tua merupakan salah satu faktor yang dapat mempengaruhi pola makan anak termasuk dalam hal konsumsi sayur dan buah pada anak. Berdasarkan penelitian di Health Centre Porto Logro Brazil pendidikan orang tua merupakan salah satu faktor yang mempengaruhi konsumsi sayur dan buah pada anak. Semakin baik tingkat pendidikan ibu maka konsumsi sayur buah pada anak juga cenderung baik. ${ }^{12,13}$ Tingkat pendidikan yang tinggi juga dapat memudahkan akses ibu untuk memperoleh pengetahuan terkait sayur dan buah. Berdasarkan hasil penelitian Yabanci ${ }^{14}$ membuktikan bahwa pengetahuan ibu berpengaruh terhadap kebiasaan makan anak dalam hal konsumsi sayur dan buah.

Tabel 1 juga menunjukkan distribusi karakteristik pada anak. Jumlah anak yang berasal dari kelas 4 SD sebesar $45 \%$ dan kelas 5 SD sebesar $55 \%$. Distribusi karakteristik jenis kelamin pada anak yaitu laki-laki sebesar $47,5 \%$ dan perempuan sebesar $52,5 \%$. Jenis kelamin merupakan salah satu faktor yang dapat mempengaruhi pola makan pada anak, termasuk dalam hal konsumsi sayur dan buah. Berdasarkan hasil penelitian Farisa $(2012)^{15}$ menunjukkan bahwa konsumsi sayur dan buah pada anak sekolah lebih baik pada anak perempuan dibanding dengan anak laki-laki.

\section{Peran Ibu sebagai Edukator}

Peran ibu sebagai edukator dapat dilihat dari ada tidaknya peran ibu dalam memberikan dukungan kepada anak untuk mengonsumsi sayur dan buah sesuai anjuran. 
Tabel 1. Distribusi Karkateristik Ibu dan Anak kelas 4 dan 5 SDN Kandang Tepus 01 dan SDN Kandang Tepus 02 Desa Senduro Tahun 2017

\begin{tabular}{lll}
\hline Karakteristik Ibu & Jumlah (n=41) & Persen (\%) \\
\hline Kelompok umur & & \\
$\quad$ Dewasa awal (26-35 tahun) & 17 & 41,5 \\
$\quad$ Dewasa akhir (36-45 tahun) & 17 & 41,5 \\
$\quad$ Lansia awal (46-55 tahun) & 7 & 17,1 \\
Pekerjaan & & \\
$\quad$ Ibu Rumah Tangga & 18 & 43,9 \\
$\quad$ Bertani/beternak & 20 & 48,8 \\
$\quad$ Wiraswasta & 3 & 7,3 \\
Tingkat pendidikan & & \\
Tidak tamat SD & 3 & 7,3 \\
Tamat SD & 29 & 70,7 \\
Tamat SMP & 7 & 17,1 \\
Tamat SMA & 2 & 4,9 \\
Kelas & 18 & 45 \\
$\quad 4$ & 22 & 55 \\
5 & & \\
Jenis Kelamin & 19 & 47,5 \\
Laki-laki & 21 & 52,5 \\
Perempuan & &
\end{tabular}

Tabel 2. Tabel Kategori Peran Ibu sebagai Edukator, Inisiator, Ketersediaan Sayur dan Buah di Rumah dan Konsumsi Sayur Buah pada Anak

\begin{tabular}{lcccc}
\hline \multirow{2}{*}{ Variabel } & \multicolumn{2}{c}{ Baik } & \multicolumn{2}{c}{ Kurang } \\
\cline { 2 - 5 } & $\mathrm{n}$ & $\%$ & $\mathrm{n}$ & $\%$ \\
\hline Peran Ibu sebagai Edukator & 9 & 21,9 & 32 & 78,1 \\
Peran Ibu sebagai Inisiator & 30 & 73,2 & 11 & 26,8 \\
Ketersediaan Sayur dan Buah & 11 & 26,8 & 30 & 73,2 \\
Konsumsi Sayur dan Buah pada Anak & 7 & 17,1 & 34 & 82,9 \\
\hline
\end{tabular}

Tabel 3. Tabel Analisis Hubungan Peran Ibu sebagai Edukator, Inisiator dan Ketersediaan Sayur dan Buah di rumah dengan Konsumsi sayur dan Buah pada Anak.

\begin{tabular}{|c|c|c|c|c|c|c|c|c|c|}
\hline \multirow{2}{*}{$\begin{array}{c}\text { Konsumsi } \\
\text { sayur dan } \\
\text { buah }\end{array}$} & \multicolumn{2}{|c|}{$\begin{array}{c}\text { Peran ibu sebagai } \\
\text { edukator }\end{array}$} & \multirow{2}{*}{$\begin{array}{c}\mathrm{p}- \\
\text { value }\end{array}$} & \multicolumn{2}{|c|}{$\begin{array}{l}\text { Peran ibu sebagai } \\
\text { inisiator }\end{array}$} & \multirow{2}{*}{$\begin{array}{c}p- \\
\text { value }\end{array}$} & \multicolumn{2}{|c|}{$\begin{array}{l}\text { Ketersediaan } \\
\text { sayur dan buah }\end{array}$} & \multirow{2}{*}{$\begin{array}{c}p- \\
\text { value }\end{array}$} \\
\hline & $\begin{array}{l}\text { Baik } \\
\text { (N\%) }\end{array}$ & $\begin{array}{r}\text { Kurang } \\
\text { (N\%) }\end{array}$ & & $\begin{array}{l}\text { Baik } \\
\text { (N\%) }\end{array}$ & $\begin{array}{l}\text { Kurang } \\
\text { (N\%) }\end{array}$ & & $\begin{array}{l}\text { Baik } \\
\text { N\%) }\end{array}$ & $\begin{array}{c}\text { Kurang } \\
\text { (N\%) }\end{array}$ & \\
\hline Baik & 4 & 3 & & 4 & 3 & & 5 & 2 & \\
\hline Kurang & $\begin{array}{c}(57,1 \%) \\
5 \\
(14,7 \%)\end{array}$ & $\begin{array}{c}(42,9 \%) \\
29 \\
(85,3 \%)\end{array}$ & 0,014 & $\begin{array}{c}(57,1 \%) \\
26 \\
(76,5 \%)\end{array}$ & $\begin{array}{c}(42,9 \%) \\
8 \\
(23,5 \%)\end{array}$ & 0,29 & $\begin{array}{c}(71,4 \%) \\
6 \\
(17,6 \%)\end{array}$ & $\begin{array}{c}(28,6 \%) \\
28 \\
(82,4 \%)\end{array}$ & 0,003 \\
\hline
\end{tabular}


Tabel 4. Tabel Analisis Hubungan Ketersediaan Sayur dan Buah di Rumah dengan Konsumsi Sayur dan Buah pada Anak dan Peran Ibu sebagai Edukator

\begin{tabular}{lccc}
\hline $\begin{array}{l}\text { Ketersediaan sayur dan buah } \\
\text { di rumah }\end{array}$ & $\begin{array}{c}\text { Baik } \\
\text { (n\%) }\end{array}$ & $\begin{array}{c}\text { Kurang } \\
\text { (n\%) }\end{array}$ & p-value \\
\hline $\begin{array}{l}\text { Konsumsi sayur buah } \\
\text { Baik }\end{array}$ & $5(71,4 \%)$ & $2(28,6 \%)$ & \\
$\quad$ Kurang & $6(17,6 \%)$ & $28(82,4 \%)$ & 0,003 \\
$\begin{array}{l}\text { Peran ibu sebagai edukator } \\
\quad \text { Baik }\end{array}$ & $5(45,5 \%)$ & $4(13,3 \%)$ & \\
$\quad$ Kurang & $6(54,5 \%)$ & $26(86,7 \%)$ & 0,028 \\
\hline
\end{tabular}

Dukungan ibu dapat ditunjukkan melalui upaya ibu dalam mengenalkan beragam jenis sayur dan buah kepada anak, memberikan informasi terkait manfaat sayur dan buah pada anak serta melakukan upaya dalam membujuk anak ketika anak menolak untuk mengonsumsi sayur dan buah. Tabel 2 menunjukkan sebagian besar ibu yang berperan kurang baik sebagai edukator adalah $78,1 \%$. Pada tabel 3 diketahui bahwa sebagian besar ibu yang berperan kurang baik sebagai edukator memiliki sebagian besar anak dengan tingkat konsumsi sayur dan buah yang rendah sebesar 90,6\%. Hasil uji statistik diketahui nilai p-value adalah 0,014. Nilai tersebut menunjukkan bahwa nilai p-value < 0,05 yang berarti ada hubungan yang bermakna antara peran ibu sebagai edukator dengan tingkat konsumsi sayur dan buah pada anak.

Peran ibu sebagai edukator merupakan suatu wujud implementasi dalam bentuk dukungan ibu kepada anak agar mengonsumsi sayur dan buah. Ibu yang selalu mengenalkan beragam jenis sayur dan buah kepada anak, selalu memberikan informasi terkait dengan pentingnya konsumsi sayur dan buah pada anak serta selalu berupaya untuk membujuk anak ketika anak menolak untuk mengonsumsi sayur dan buah dapat merangsang anak untuk meningkatkan konsumsi sayur dan buah hingga sesuai dengan yang dianjurkan oleh WHO.

Berdasarkan Tabel 4 diketahui bahwa ketersediaan sayur dan buah di rumah lebih baik pada ibu yang berperan baik sebagai edukator yaitu sebesar $55,6 \%$. Pada ibu yang telah berperan baik sebagai edukator, ketersediaan sayur dan buah di rumah telah baik yaitu sebesar $18,8 \%$. Ada hubungan yang bermakna antara peran ibu sebagai edukator dengan ketersediaan sayur dan buah di rumah ( $p$-value $=0.028$. Hasil penelitian ini sesuai dengan penelitain Farisa $(2012)^{15}$ yang menunjukkan ada hubungan secara langsung antara dukungan orang tua dengan konsumsi sayur dan buah pada anak dengan syarat ketersediaan sayur dan buah cukup di rumah.

\section{Peran Ibu sebagai Inisiator}

Peran ibu sebagai inisiator dapat dilihat dari ada tidaknya peran ibu dalam menentukan makan keluarga. Peran ini nampak dari eksistensi ibu dalam menentukan menu, anggaran belanja hingga pembelian sayur dan buah serta menentukan jenis olahan untuk sayur dan buah. Sebesar $73,2 \%$ ibu berperan baik sebagai inisiator. Pada tabel 3 diketahui bahwa sebagain besar ibu yang berperan baik sebagai inisiator memiliki anak dengan tingkat konsumsi sayur dan buah yang kurang yaitu $86,7 \%$. Hasil uji statistik diketahui nilai $p$-value adalah 0,293 berarti tidak ada pengaruh yang bermakna antara peran ibu sebagai inisiator terhadap konsumsi sayur dan buah pada anak. Walaupun ibu telah berperan baik sebagai inisiator namun hal tersebut tidak selalu berkaitan dengan konsumsi sayur dan buah pada anak. Peran ibu dengan memberi kebebasan kepada anak untuk memilih menu dan menentukan sayur dan buah yang akan dibeli pada hari tersebut menyebabkan anak mau untuk mengonsumsi sayur dan buah karena buah dan sayur tersebut dibeli berdasarkan keinginan mereka. Beberapa ibu bekerja sebagai petani yang harus bekerja selama 9 sampai 12 jam perhari dari pagi hingga sore hari. Pemilihan menu dan kegiatan berbelanja diserahkan kepada anak tertua atau suami dikarenakan ibu sudah 
harus berangkat ke sawah di pagi hari dan tidak memiliki waktu untuk berbelanja bahan makanan.

\section{Ketersediaan Sayur dan Buah di Rumah}

Jenis makanan yang tersedia lebih banyak mempunyai peluang yang besar untuk dikonsumsi, sedangkan jenis makanan yang tidak tersedia tidak akan di konsumsi. Perlu dilakukan upaya untuk menyediakan lebih banyak buah di tempat makan, di sekolah dan di rumah sehingga dapat meningkatkan konsumsi sayur dan buah $^{16}$. Tabel 2 menunjukkan bahwa ibu yang memiliki ketersediaan sayur dan buah yang kurang di rumah sebesar $73,2 \%$ dari 41 responden ibu. Sebagian besar ibu yang memiliki ketersediaan sayur dan buah yang kurang di rumah, sebagian besar tingkat konsumsi sayur dan buah pada anak termasuk dalam kategori kurang yaitu $82,4 \%$ dengan nilai p-value yaitu 0,003 yang berarti bahwa ada pengaruh antara ketersediaan sayur dan buah di rumah terhadap konsumsi sayur dan buah pada anak. Hasil penelitian ini sejalan dengan hasil penelitian Bahria \& Triyanti yang membuktikan bahwa ada hubungan antara ketersediaan sayur dan buah di rumah dengan konsumsi sayur dan buah pada anak usia sekolah ${ }^{17}$.

\section{KESIMPULAN}

Berdasarkan hasil penelitian diketahui bahwa faktor yang berhubungan dengan konsumsi sayur dan buah pada anak adalah peran ibu sebagai edukator dan ketersediaan sayur dan buah di rumah sedangkan peran ibu sebagai inisiator tidak berhubungan dengan konsumsi sayur dan buah pada anak.

\section{ACKNOWLEDGEMENT}

Terima kasih dan penghargaan diberikan penulis kepada seluruh staf pengajar program studi ilmu gizi Universitas Airlangga atas bimbingan yang telah diberikan.

\section{REFERENSI}

1. Kementrian Kesehatan RI.Riset Kesehatan Dasar (RISKESDAS 2013). Jakarta:Penelitian dan Pengembangan Kesehatan RI, 2013.pp.142.

2. Zaborskis A, Moceviciene R, lannotti RJ. The Influence of Chronological Period of Data Collection on Differences in Reported Dietary Intake Among SchoolAged Children Surveyed in 39 Countries.Journal of Nutrition Education and Behavior 2014; 46:(45).

3. Folkvord F, Anastasiadou DT, Anschutz D. Memorizing Fruit : The effect of a fruit memory-game on children's fruit intake.Journal of Preventive Medicine Reports 2016;5: 106-111.

4. Ray C, Matta S, Lehto R, Roos G, Roos E. Influencing factors of children's fruit, vegetable and sugar-enriched food intake in a Finnish preschool setting-Preschool personnel's perceptions.Journal of Appetite 2015;103:72-79.

5. World Health Organization. WHO Fruit and Vegetable Promotion Initiative.Switzerland, Geneva 2003.

6. Grober U. Mikronutrien: Penyelarasan Metabolik, Pencegahan dan Terapi.Jakarta: Kedokteran EGC 2009;pp 197-198.

7. Harris TS, Ramsey M. Paternal Modeling, Household Avalibilty And Paternal Intake As Predictors Of Fruit, Vegetable And Sweet Beverage Consumption Among African American Children.Department of Psychology 2014; 85: 171-177.

8. Sharps $M$, Higgs $S$, Blissett J, Nouwen A, Chechlacz $M$, Allen HA, Robinson $E$. Examining evidence for behavioural mimicry of parental eating by adolescent females : An observational study.Journal of Appetite 2014;89: 56-61.

9. Leech, R. M., McNaughton, S. A., Crawford, D. A., Campbell, K. J., Perason, N., and Timperio, A.Family food involvement and frequency of family dinners melas among Australian Children aged 10-12 years. Cross-sectional and longitudinal associations with dietary 
patterns.Journal of Appetite, 2014;75:6470.

10. McGuigan, Kathryn.The Role of Mothers in Family Health.Thesis.Massey University, New Zealand 2012.

11. Putri, Dixy F. T. P. dan Kusbaryanto.Perbedaan Hubungan antara lu Bekerja dan Ibu Rumah Tangga terhadap Tumbuh Kembang Anak Usia 25 Tahun.Jurnal Mutiara Medika 2012;12(3);143-149.

12. Valmorbida, Julia L., Vitolo, Marcia R.Factors associated with low consumption of fruits and vegetables by preschoolers of low socio-economic level.Journal de Pediatria, 2014;90(5):464-471.

13. Mohammad, Andika dan Madanijah, Siti.Konsumsi Buah dan Sayur Anak Usia Sekolah Dasar di Bogor. Jurnal Gizi Pangan, 2015 10(1):71-76.
14. Yabanci, N., Kisac, I. Karakus, Suran Z.The effect of mother's nutritional knowledge on attitudes and behaviors of children about nutrition. Journal Social and Behavioral Science,2014;116.

15. Farisa, Soraya.Hubungan Sikap, Pengetahuan, Ketesediaan dan Keterpaparan Media Massa dengan Konsumsi Buah dan Sayur pada Siswa SMPN 8 Depok Tahun (2012).Skripsi.Universitas Indonesia.2012.

16. Reynold, Kim D., Knut-Inge Klepp \& Amy L., Yaroch.Strategi Gizi Kesehatan Masyarakat untuk Intervensi di Tingkat Ekologis di dalam Michael J. Gibney.Gizi Kesehatan EGC.2004.

17. Bahria dan Triyanti.Faktor-faktor yang terkait dengan konsumsi buah dan sayur pada remaja di SMA 4 Jakarta Barat.Jurnal Kesehatan Masyarakat Andalas, 2010;4:2. 